\title{
LAS NARRACIONES GRÁFICAS DE JULIO CORTÁZAR: HIBRIDACIONES Y EXPRESIONES CRÍTICAS
}

\author{
JULIO CORTÁZAR'S GRAPHIC NARRATIVES: \\ HYBRIDIZATION AND CRITICAL EXPRESSIONS
}

\author{
David García-Reyes \\ Universidad de Concepción. Concepción. \\ Chile \\ davgarciareyes@gmail.com
}

\begin{abstract}
Resumen: La obra de Julio Cortázar destaca por su modernidad y por la capacidad del escritor argentino para proyectar sus imaginarios en ámbitos como la historieta. Cortázar demostró interés y curiosidad por diversos medios artísticos, desde la música al cine. Las obras de Cortázar como guionista de historietas confirman la coherencia de su obra y la evolución de esta. La investigación aborda el estudio de la significación e importancia de Fantomas contra los vampiros multinacionales (1975) y La raíz del ombú (1981), narraciones gráficas que manifiestan el conocimiento del medio por parte del escritor argentino y que ahondan en una visión crítica del mundo, reivindicando la figura del intelectual y su posición responsable, denunciando los abusos y atrocidades perpetrados en América Latina.
\end{abstract}

Palabras clave: Cortázar, historieta, hibridaciones, imaginarios latinoamericanos.

\begin{abstract}
Julio Cortázar's work is characterized by its modernity. He was interested in all the types of narrative media, from music to cinema, projecting also his fictional imaginaries in comics. Cortázar's graphic narratives confirm the coherence and the evolution of his work. The study addresses the significance and importance of Fantomas contra los vampiros multinacionales (1975) and La raíz del ombú (1981), comics in which the knowledge of graphic narrative by the Argentine writer is shown. Both narrations have a critical vision of the world, denouncing the abuses and atrocities committed in Latin America.
\end{abstract}

Keywords: Cortázar, comic, hybridizations, Latin American Imaginaries.

Recibido: 15/09/2020. Aceptado: 28/12/2020. 


\section{Introducción}

T a obra de Julio Cortázar tuvo una profunda significación política. Del $\checkmark$ mismo modo, evidencia una diversidad en los medios en los que se expresa que favorece un análisis que va desde las intersecciones filmoliterarias a los tránsitos secuenciales de la producción artística cortazariana. La significación y proyección de la obra del escritor argentino se incluye en los estudios literarios, pero presenta cualidades de las que se han impregnado las más diversas manifestaciones, motivando también que los imaginarios cortazarianos se vean proyectados en la cultura popular iberoamericana.

El interés que suscita la prosa de Cortázar en el cine se despliega en las filmografías de muy distintos cineastas como Manuel Antín, Osias Wilenski, Michelangelo Antonioni, Luigi Comencini, Patrick Ledoux, Jean-Luc Godard o Nina Grosse. El grueso de esta producción fílmica es recogida y analizada en el trabajo de Bruno López Petzoldt (2014) y este precedente permite valorar el estudio de la dimensión creativa de Cortázar en toda su extensión, en relación con la producción del escritor como guionista de historietas y la consideración por parte del medio secuencial de la figura y la obra cortazarianas, puesto que a pesar de las diferencias entre las narraciones literarias, audiovisuales o secuenciales, el análisis permite identificar las convergencias y divergencias que traspasan a los tres medios e indagar en los caminos éticos y estéticos que se generan en estos procesos creativos (García-Reyes, 2020: 272-273).

La actividad creativa de Cortázar permite verificar y comprender la seducción que los relatos visuales estimulaban en el escritor nacido en Bruselas. El autor argentino expresó con frecuencia su fascinación por el mundo de las imágenes, desde los fotogramas en movimiento a las más variadas expresiones plásticas y gráficas. Cuando se explora el interés de Cortázar por la historieta se advierte cierta omisión a la hora de evaluar la importancia que las narraciones gráficas tuvieron en las rutinas lectoras del escritor. Esta tendencia se observa al acudir, por ejemplo, a algunos de los trabajos de Jesús Marchamalo sobre Cortázar. En su ensayo sobre la exploración de la biblioteca personal ${ }^{1}$ de Julio Cortázar; el escritor español se ocupa de

${ }^{1}$ Los libros de la biblioteca personal del escritor se encuentran depositados en la Fundación Juan March de Madrid, fondos que fueron donados en 1993 por Aurora Bernárdez, 
indicar la atención por las artes plásticas y las vanguardias pictóricas en las lecturas del escritor argentino, una propensión manifestada en los fondos de esta temática que se pueden consultar en la biblioteca cortazariana (Marchamalo, 2011: 32-33). Además, Marchamalo se cuestiona si Cortázar dibujaba o no, y sin llegar a despejar la incógnita de la inquietud del escritor por el dibujo, sí se puede rastrear una serie de trazos pictóricos y garabateos gráficos en algunos de los más de cuatro mil libros de su biblioteca. Una circunstancia que permite observar la especial predilección del escritor por los juegos de líneas y las espirales (Marchamalo, 2011: 96101), formas figurativas o abstractas, bosquejos iconográficos que, sin ir demasiado lejos, remiten a diversas interpretaciones metafóricas o pueden aludir a representaciones esquematizadas de la estructura narrativa de $\mathrm{Ra}$ yuela (1963), novela capital en la producción de Cortázar y epítome del denominado boom de la literatura latinoamericana.

El estudio de Jesús Marchamalo sobre los libros de Cortázar es un valioso acercamiento al autor como lector. Además, dentro de la selección del trabajo del ensayista en su orientación hacia la obra y la vida de Cortázar, destaca su faceta como guionista de cómics. Concretamente en la novela gráfica Cortázar (2017), con guión de Marchamalo y Marc Torices ocupándose del apartado gráfico. Paradójicamente, esta notable biografía gráfica no llega a ocuparse de la faceta historietística de Cortázar ${ }^{2}$, pero a cambio ofrece un imaginario cortazariano lleno de imágenes y evocaciones sensoriales, secuencias cromáticas y visuales que tienen a la propia biografía de Cortázar como motor de la narración, centrada en sus periplos sentimentales y en otras peripecias vitales respecto de su vinculación y cercanía con los movimientos sociales y políticos de América Latina. Por lo tanto, como en toda biografía novelada, por acción, selección u omisión, existen cuestiones que no llegan a abordarse. De esos episodios o circunstancias esquivadas en los dos libros comentados de Marchamalo

\footnotetext{
viuda y legataria universal de Cortázar.

${ }^{2}$ En Cortázar, el escritor es el protagonista absoluto de la biografía gráfica y en la misma, de nuevo, quedan obviadas sus historietas. Es llamativa la elusión de las aportaciones cortazarianas a la historieta, porque, aunque no sean imprescindibles en el ámbito global del medio sí lo son en su audacia experimental, temática y estilística. Descuido o no, resulta comprensible si se piensa en la abundante producción del escritor y en otros episodios de su vida, dado que la biografía tampoco se ocupa de las incursiones fílmicas del escritor que, siendo más notorias, son soslayadas en el relato gráfico.
} 
se obvia algo fundamental y muy procedente para este estudio.

Entre los miles de títulos y volúmenes de la biblioteca que custodia la Fundación Juan March se pueden encontrar varios álbumes y libros de historieta ${ }^{3}$. En los fondos de la institución madrileña se localizan diversas narraciones gráficas como los relatos ilustrados de Dancing cats and neglected murderesses (1980) de Edward Gorey; Scat: una interpretación gráfica del jazz (1974) del ilustrador uruguayo Hermenegildo Sabat ${ }^{4}$; el libro Tango (1982) integrado por dibujos del pintor argentino Ricardo Carpani o la autobiografía historietística (1973) del humorista gráfico español Chumy Chúmez. En la biblioteca de Julio Cortázar se pueden encontrar dos ediciones de historietas francesas de finales del siglo XIX reeditadas en 1977 como Les Facéties du sapeur Camember (1890-1896) y L'Idée dice du savant Cosinus (1893), obras del historietista Cristophe, que influyeron decisivamente en la bande dessinée (BD) francesa posterior. Entre otros títulos significativos, la biblioteca contiene también Hold me! (1962) volumen con tiras cómicas del humorista gráfico estadounidense Jules Feiffer; una reedición de 1977 del álbum de BD Il y a un sorcier à Champignac (1951), perteneciente a la serie de Spirou realizada por André Franquin y Henri Gillain; La buena mesa: introducción a la gastronomía (1980) de Quino y también el recopilatorio de tiras cómicas The People's Doonesbury: notes from underfoot, 1978-1980 (1981), antología del historietista norteamericano Garry Trudeau. Además, entre los libros de Cortázar tienen cabida y resultan especialmente destacables dos ejemplos de obras de artistas latinoamericanos de la historieta: Comix-arte de Zalathiel (1977) recopilatorio de relatos gráficos y experimentales del artista e historietista mexicano Zalathiel Vargas y la edición original francesa de Les Yeux du chat (1978), que cuenta con guión de Alejandro Jodorowsky y grafismo de Moebius. Los autores señalados exhiben una enorme significación en el medio secuencial, destacando la capacidad de estos para la transgresión en el cómic.

${ }^{3} \mathrm{El}$ fondo de la fundación ha actualizado las ediciones más recientes de Fantomas contra los vampiros multinacionales (2002) y La raíz del ombú (2004). Además, se pueden encontrar las primeras ediciones de las anteriores y la versión húngara Fantomas a vámpírok ellen (1978), dedicada por la traductora Éva Dobos. En este aspecto, lo que más llama la atención tal vez sea la ausencia en los fondos de la biblioteca de "La inteligencia en llamas", la historieta mexicana que empuja a Cortázar a escribir Fantomas.

${ }^{4}$ Artista con el que Cortázar colaborará posteriormente. 
Aunque no muy numerosos, los ejemplos apuntados constatan el gusto por las historietas underground y por las representaciones alternativas del cómic, manifestaciones contemporáneas al propio Cortázar que enfatizan sus intereses y las afinidades que se reflejan en su producción gráfica. La pesquisa de estos libros permite entender el conocimiento de la historieta por parte del escritor y es un síntoma de su evolución como lector desde 1951, momento en el que se establece en Francia, permitiendo trazar algunas señas del alcance de la historieta en Cortázar a lo largo de las décadas posteriores y que se relaciona a la descripción que Ana Merino hace del escritor mexicano Carlos Monsiváis como un tipo de crítico vinculado afectivamente al consumo y al coleccionismo de cómics, sin que esto afectase a sus posiciones ideológicas de izquierda (Merino, 2003: 269). Las características de su amigo Monsiváis pueden extrapolarse al propio Cortázar.

$\mathrm{Al}$ estudiar la faceta secuencial del escritor se pueden advertir algunas de sus preferencias como lector de cómics o historieta, permitiendo apreciar su conocimiento y competencia a la hora de encarar el medio. Como muy bien apuntaba Jaime Alazraki en relación con la obra literaria de Julio Cortázar, el escritor argentino "se aventuraba por territorios no descubiertos todavía" (Alazraki, 1989: 3). El afán exploratorio del creador argentino le lleva a emprender incursiones en la historieta, interesado por las posibilidades del noveno arte, junto con la coyuntura y recepción que generaba el medio. La historieta no le era ajena como lector, circunstancia que se aprecia en la disposición de aplicar su versatilidad narrativa y experimental también en las narraciones gráficas. La significación y relevancia del escritor como guionista de historieta se manifiestan primero en Fantomas contra los vampiros multinacionales: una utopía realizable (1975) y luego en La raíz del ombú (1981). Las dos narraciones de Cortázar resultan tan representativas como singulares, pero no son únicas dentro de su producción.

El trabajo de Cortázar con artistas e ilustradores fue frecuente y fructífero como demuestran sus colaboraciones con el artista Hermenegildo Sabat en el libro Monsieur Lautrec (1974) en el que se percibe la sintonía del escritor argentino con el relato gráfico y su proyección narrativa ${ }^{5}$, cir-

${ }^{5}$ Este libro ilustrado fue publicado en Francia y contaría con una edición española renombrada Monsieur Lautrec. Un Gotán para Lautrec (1980). En la trama, Cortázar iden- 
cunstancia análoga a su colaboración con Pat Andrea, artista expresionista holandés que, tras marcharse de la Argentina de la Junta Militar, buscaba que un escritor como Cortázar prologase su trabajo gráfico sobre las experiencias brutales de las que fue testigo en su estancia en el país. La colaboración se transforma en un libro ilustrado como La puñalada. Le Tango du retour (1982), desarrollando la propuesta original de Andrea con la incorporación de un relato escrito para el libro por Cortázar.

Desaparecido el escritor, son otros los que se ocupan de ilustrar obras de Cortázar. Una iniciativa emprendida por el sello Libros del Zorro Rojo que se concreta con Reunión (2007), relato de Cortázar ambientado en la Revolución cubana ${ }^{6}$, publicado previamente en Todos los fuegos el fuego (1966), y que aborda las tribulaciones de un líder guerrillero que se identifica con el revolucionario argentino Ernesto Che Guevara y su destacamento, buscando encontrarse con Fidel para iniciar la ofensiva final. Las quince ilustraciones bitono demuestran la potencia y la maestría en blanco y negro del dibujante Enrique Breccia7 . La misma editorial publica otro cuento notable de Cortázar, El perseguidor (2009), que es ilustrado con maestría por el historietista argentino José Muñoz, y se afana en replicar la catarata narrativa que es el relato cortazariano, impregnada por el mundo y los ritmos de la música jazz y que es un homenaje al saxofonista Charlie Parker. La veintena de ilustraciones en blanco y negro de Muñoz retoma muchas de los estilemas de su trabajo en la historieta, componiendo una narración figurativa del París de los cincuenta y el gusto por la música jazz del momento, encapsulando una época del mismo modo que provoca Cortázar en su cuento.

tifica a la prostituta Mireille -modelo de Henri de Toulouse-Lautrec en el burdel de la Rue de les Moulins- con la Rubia Mireya, legendario y mítico personaje femenino del Buenos Aires de los arrabales y el Tango de principios del siglo XX.

${ }^{6}$ La revelación ideológica a la realidad de América Latina y la toma de conciencia de Julio Cortázar se produce al viajar a Cuba en 1963. El escritor rechazaba y se sentía muy alejado de las grandes manifestaciones del peronismo en su Argentina natal. En cambio, se identificó con las expresiones, los anhelos y las esperanzas que el pueblo cubano depositó en la Revolución (González Bermejo, 1978: 120). Una adhesión a la Revolución cubana que no era monolítica, pues Cortázar tuvo importantes disensos a propósito del nivel de su compromiso político con Oscar Collazos, José María Arguedas y Liliana Heker (Navarro, 2020: 156).

${ }^{7}$ Visualmente evoca la historieta Vida del Che (1968), primer trabajo firmado por Enrique Breccia compartiendo créditos en el arte con su padre Alberto Breccia y con guión de Héctor Germán Oesterheld. 
En este apartado, conviene señalar que una parte de la crítica precedente estudia las narraciones figurativas de Cortázar como instancias literarias y no un estudio conjunto de las historietas, obviando el potencial visual e iconográfico que despliega Cortázar en sus incursiones secuenciales -inclusive las que inspira-, y quedando huérfana la concepción total de las historietas del escritor. Así, la investigación pretende realizar un estudio integrado que dé cabida al sello autoral de Cortázar y también identificar el valor y las aportaciones visuales contenidas en sus propuestas historietísticas.

\section{El valor de la historieta en América Latina}

A la hora de emprender un estudio en el que la narración es dual por su naturaleza híbrida, hay que pensar en las diferencias que se establecen entre los diferentes relatos ilustrados: una serie de particularidades que se desarrollan a lo largo de toda la historia de la humanidad en una gran plétora de narraciones visuales. Estas posibles diferencias se pueden identificar respecto de un relato literario ilustrado, la viñeta de humor gráfico de un diario, un mural con una secuencia de imágenes, un retablo hagiográfico, las ilustraciones de un códice medieval o las huellas pictóricas de una cueva rupestre, etc., y que, como señala Antonio Altarriba, permite presentar estos contrastes con la historieta no sólo desde una distancia cronológica sino también al observar un discurso de origen filológico frente a los elementos comunes que convergen con el lenguaje pictográfico y con una amplia galería icónica que es afín a las manifestaciones artísticas señaladas (Altarriba, 2011: 9). En estos caminos, llenos de intersecciones y obstáculos, los criterios restrictivos empobrecen los estudios del cómic. Esta paradoja se combate con la aplicación de un aparato crítico y riguroso que apela a un reconocimiento académico que nos permite pensar la historieta con la misma consideración que se otorga a las más variadas manifestaciones artísticas, desde la escultura, los tapices, las vidrieras, la cerámica o la pintura, lenguajes y formas de expresión que han recurrido a secuencias narrativas más allá de su acabado o de sus virtudes estéticas o plásticas (Altarriba, 2011: 10). 
Una de las diferencias fundamentales de la historieta con otras artes visuales y similar a la distribución comercial del cine es la producción y divulgación seriadas de la historieta. En este sentido, el noveno arte contempla y reconoce su estatuto en "la condición artística al tiempo que necesita su carácter industrial - las peripecias técnicas de su reproductibilidad" (Altarriba, 2011: 11). Lo popular y lo accesible son atributos que, sin duda, Cortázar valora para acercarse e introducirse en el medio. Pero no solamente será la oportunidad de alcanzar a un público mayor, que en ambos casos resulta discutible, porque tanto Fantomas contra los vampiros multinacionales: una utopía realizable (1975) como La raíz del ombú (1981), no obtuvieron la difusión comercial que podría esperar el escritor argentino. Acercarse al medio le proporciona a Cortázar otras perspectivas y se reafirma en la idea de un creador que se propone la máxima de "contar historias en imágenes [...] primera y principal manera de dejar constancia de nuestra experiencia o de nuestros deseos, en cualquier caso de ese indicio básico de humanidad que es nuestra capacidad de representación simbólica” (Altarriba, 2011: 12).

Volviendo de nuevo a las nociones de la historieta en los estudios académicos, Ana Merino se preguntaba: “¿por qué la academia tardó tanto en reconocer las dimensiones estético-narrativas del medio en América Latina?” (Merino, 2011: 14). La investigadora aporta varias respuestas, entre ellas se encuentra la corriente de los que continúan la senda iniciada por el ensayo Para leer al Pato Donald: Comunicación de las Masas y Colonialismo (1971) de Ariel Dorfman y Armand Mattelart. Algunos de los planteamientos de Dorfman y Mattelart resultaban acertados en su crítica a la propagación del imperialismo estadounidense a través de muchos de los productos de la cultura popular, entre ellos la historieta y los dibujos animados. Sin embargo, muchos emplearon esa coartada y redujeron el valor de la historieta a esos productos culturales exportados por los Estados Unidos, omitiendo negligentemente el reconocimiento de una de las etapas doradas de la historieta de América Latina. Esa sesgada tendencia, hizo que muchos académicos fueran incapaces de "definir o identificar las dimensiones ideológicas de la historieta autóctona latinoamericana” (Merino, 2011: 14). Esta serie de exclusiones perpetuó los prejuicios, denostándose sistemáticamente el medio secuencial a lo largo de las últimas décadas del siglo XX y ejerciendo una prescripción que ha configurado "una separación 
entre las culturas representativas canónicas y otros objetos culturales entre los que se encontraría arrinconada la historieta en general.” (Merino, 2011: 14).

Afortunadamente las circunstancias descritas han cambiado y las mismas no impidieron la predisposición de Cortázar hacia el medio, dado que ignoró las percepciones descritas e instaladas en una gran parte de la intelectualidad iberoamericana que no podía, no sabía y no quería descubrir los lenguajes, las formas, los temas y los códigos del cómic. Muchas de las premisas de la historieta latinoamericana eran afines a la vocación experimentalista de Cortázar, integrante como uno de "los creadores latinoamericanos más carismáticos [que] fueron conscientes de la importancia de sus obras y de las ambiguas relaciones que tenían con ellos los desconocedores del campo." (Merino, 2011: 14). Ese limbo de desconocimiento y negación ha supuesto un enorme menoscabo en la apreciación y consideración del medio y de sus artífices. La nómina de afrentas hacia los grandes creadores latinoamericanos como Rius, Juan Padrón, Juan Acevedo, Themo Lobos, Alberto Breccia, Oski, Quino o Hugo Germán Oesterheld es abundante. Los nombres citados y sus obras son merecidamente reconocidas como patrimonio de la cultura de América Latina. Entre la ceguera de muchos, Cortázar supo ver el valor y la calidad de los mencionados historietistas y aprovechar las posibilidades narrativas y estéticas que le ofrecía la historieta.

No resulta extraño comprobar cómo Cortázar, al igual que Oesterheld ${ }^{8}$, veía en la literatura o el cómic un instrumento para abordar la crítica y estimular la reflexión de los lectores en torno a cuestiones capitales. El formato, el medio, era indiferente, pero sí resultaba esencial llegar al corazón de las cuestiones que vertebraban un cambio en la relación de fuerzas que colisionaron a finales del siglo XX en América Latina y en el fondo a la obra de ambos creadores argentinos les une la perseverancia por denunciar el imperialismo rampante, el latrocinio poscolonial y la lucha común desde sus trincheras frente a las derivas autoritarias violentas que, secularmente, venía sufriendo el continente.

${ }^{8}$ La diferencia fundamental es el posicionamiento de uno y otro. Cortázar era un antiperonista y un intelectual antimperialista frente a Oesterheld, que era un creador de enorme conciencia social y militante montonero en sus últimos años, militancia que convertiría a Oesterheld y a sus hijas en víctimas de la barbarie. 


\section{Narrativas híbridas en Fantomas}

La primera incursión de Cortázar en el medio se va a producir como una reacción creativa pero también crítica. Esta reacción surge tras la publicación de una historieta en la que la imagen de Cortázar es tomada sin su permiso para incluir a un personaje que cuenta con los atributos del escritor. Esta relativa vulneración de la figura pública del intelectual argentino tuvo como responsables al guionista Gonzalo Martré y al dibujante Víctor Cruz, dos artistas mexicanos de la historieta que publican "La inteligencia en llamas"9 en 1975. La historieta, de unas treinta páginas y en formato grapa se centra en cómo el personaje de Fantomas descubre una conspiración que se ocupa de la eliminación y quema de libros. Además, diversos escritores son perseguidos y amenazados, entre ellos aparecen por las viñetas Alberto Moravia, Octavio Paz, Susan Sontag y el propio Cortázar. El complot es impulsado por una corporación empresarial, una sociedad que es dirigida por un fanático empresario francés que anhela la destrucción de los libros como fuente de los males de la humanidad y que se ve neutralizada por Fantomas ${ }^{10}$.

Cuando en la célebre entrevista de Joaquín Soler-Serrano, televisada el 20 de marzo de 1977, el periodista le pregunta a Cortázar por un libro poco conocido en España, llamado Fantomas, el escritor argentino le dice que no es un libro, que se trata de un cómic. Este matiz no es trivial porque es el autor el que se refiere al libro como un cómic y, prefiere eso sí, la denominación de historieta, más próxima a su acervo cultural. Cortázar le explica

\footnotetext{
${ }^{9}$ El título está extraído de varios versos del poema "Muerte sin fin" (1939) del poeta mexicano José Gorostiza.

${ }^{10}$ El origen del personaje de Fantômas se remonta a 1910 en Francia. El editor Arthème Fayard encarga una serie de novelas de detectives a los escritores Pierre Souvestre y Marcel Allain. Las tramas tienen como protagonista a Fantômas, genio del crimen y archivillano enmascarado que será objeto de diferentes adaptaciones en el cine silente y en el sonoro. Además, a partir de la década de 1950 el cine y la historieta (Artiaga, 2013) -tanto en Francia como en México- se ocupan de revitalizar su figura. A mediados de los sesenta el personaje protagoniza Fantomas: la amenaza elegante, una serie de historietas a lo largo de las dos décadas siguientes publicadas por la Editorial Novaro de México, y la que tiene a Cortázar como personaje es la entrega 201 publicada en 1975. En la saga de historietas mexicanas, Fantômas pasa a ser Fantomas y se convierte en una suerte de héroe justiciero con trazas progresistas, alejándose de la concepción original del personaje y su vinculación al mal y al mundo del crimen.
} 
a Soler-Serrano que los motivos de no haberse distribuido en España están motivados porque aborda cuestiones surgidas en las sesiones del Tribunal Russell II, su condena explícita hacia los regímenes dictatoriales del Cono Sur y la complicidad de los Estados Unidos. Recurriendo al comentario de un amigo, el escritor comenta con irónica vanidad que, cuando un escritor entra en un cómic, es el colmo de la celebridad. Cortázar explica que realiza la apropiación ${ }^{11}$ de la historieta del mismo modo que a él no se le pide permiso para que sirva como personaje del cómic. El escritor recrea la historieta mexicana y dirige el foco de esta a otro espacio, amplificando el precedente historietístico. Asimilando también el relato de espionaje e intrigas internacionales, que se transforma en Cortázar en un relato hibrido muy sugestivo que denuncia el Imperialismo norteamericano y la imposición del modelo de los Estados Unidos, que quiere convertir América Latina en una factoría. El escritor explica que el formato híbrido de relato literario y secuencial se distribuyó en sesenta mil copias en los quioscos mexicanos (Soler-Serrano, 1977a, 22:31-28:18).

La pregunta de cómo Cortázar supo de la existencia de la historieta se debe a Guillermo Piazza. Piazza, editor argentino afincado en México, trabajaba en Editorial Novaro y por esa razón le manda la historieta. La respuesta de Cortázar es elaborar una nueva obra con la intención de emplear algunas páginas de "La inteligencia en llamas", que le sirven para desarrollar su propuesta tomando la historieta preexistente, estableciendo "un puente entre la cultura letrada y la popular y la capacidad de ambas para representar las problemáticas de la sociedad" (Merino, 2003: 67). El libro se publica bajo el sello Excélsior, editorial y periódico del mismo nombre en el que Piazza también colaboraba. Todo ello lo explica el escritor Gonzalo Martré, guionista de "La inteligencia en llamas":

El inefable Piazza, amigo y paisano de Cortázar remitió un ejemplar al célebre autor quien vivía en París desde hacía algunos años, exiliado. Al verse como personaje de historieta sin habérsele pedido permiso para ello, Cortázar halló el pretexto ideal para difundir sus ideas en una his-

${ }^{11}$ Como si se tratase de un juego de matrioskas de la apropiación, en los años posteriores a la publicación del libro de Cortázar se sucedieron distintas ediciones de Fantomas por el mundo, autorizadas o piratas, entre las que destaca el trabajo gráfico de la versión polaca Fantomas przeciw wielonarodowym wampirom (1979), obra del artista Jerzy Skarżyński. 
torieta, medio para hacerlas llegar a un lector distinto al habitual de su obra. Esto es, ampliar considerablemente el alcance de sus ideas. Piazza era colaborador en la página editorial del periódico Excélsior y le fue fácil convencer a Julio Sherer (sic) su director de que publicara un folletín de Cortázar. Por su parte, Scherer no lo pensó dos veces, aceptó en el acto la propuesta Cortázar-Piazza (Martré, 2014).

De esta forma, con bastante celeridad y una edición de miles de ejemplares se publicó Fantomas contra los vampiros multinacionales: una utopía realizable en 1975. El propio artefacto narrativo e híbrido de Cortázar se apropiaba de las viñetas de Martré y Cruz, constituyéndose en una narración que intercalaba algunas de las páginas del cómic mexicano sobre la experiencia del escritor como miembro del Tribunal Russell II ${ }^{12}$ (1974-1976). El Tribunal se reunió en tres sesiones en Roma (1974 y 1976) y Bruselas (1975) para evaluar e identificar las violaciones de los Derechos Humanos que se estaban produciendo en América Latina con el establecimiento de políticas y regímenes autoritarios que suprimían derechos fundamentales y perseguían cualquier disenso con actuaciones atroces y criminales. El libro se centra particularmente en lo que sucedía en Chile en ese momento y los actos criminales perpetrados durante la dictadura liderada por Augusto Pinochet.

En Fantomas, Cortázar arma un relato que juega con la experimentación, gráfica y literaria, tan del gusto del creador argentino. Al incluir las páginas de la historieta previa, el autor argentino ofrece un sombrío escenario en el que el lector se sumerge en las actas del Tribunal y grafica cómo las dictaduras latinoamericanas actuaban, en connivencia con los servicios de inteligencia norteamericanos, persiguiendo y aniquilando cualquier forma de subversión que amenazase sus intereses políticos y económicos. En ese contexto, el personaje de Fantomas impulsado por Cortázar como personaje/narrador, decide actuar orientado por las directrices del intelectual (Mac-Millan Kuthe, 2017: 180). Conminado por el escritor pone de mani-

${ }^{12} \mathrm{Su}$ precedente fue el primer Tribunal Russell (1966-1967), conocido también como Tribunal Internacional sobre Crímenes de Guerra, tribunal independiente de opinión internacional integrado por personalidades de todo el mundo que se reunió en Estocolmo y Copenhague para investigar la intervención de los Estados Unidos en Vietnam. Cortázar cedió los derechos de autor de Fantomas al Tribunal Russell. 
fiesto la complicidad de la CIA en la oleada de abusos, olvidados o ignorados interesadamente por los medios, dejando a la opinión pública internacional huérfana de lo que ocurría en América Latina. El componente ético de la obra cortazariana presenta en Fantomas una irreductible capacidad para enfrentarse a la opacidad informativa y combatir, a su manera, lo que ocurría en los países del Cono Sur de América. En la naturaleza dual de este dispositivo narrativo se observa la pericia de Cortázar para divulgar los resultados de las deliberaciones del Tribunal Russell II. Aunque pueden contemplar variadas denominaciones, Fantomas, por sus heterogéneas características, se erige en un objeto que Mary Fleur Mac-Millan Kuthe define como "inclasificable, que mezcla un eje narrativo central con imágenes, recortes de diario, fotografías y dibujos" (Mac-Millan Kuthe, 2017: 173), "es un texto híbrido [...] que se mueve en varios niveles narrativos y de realidad” (Mac-Millan Kuthe, 2018: 747), nociones que permiten afirmar que se trata de una narración figurativa extraordinaria que escapa del canon, alejándose de géneros y de definiciones ortodoxas.

Mac-Millan Kuthe (2018) arroja una reflexión de enorme lucidez al plantear que el cómic actúa como seducción, porque tomando la afirmación de Vladek Spiegelman, protagonista de Maus: Relato de un superviviente $^{13}$ : la gente no desea escuchar historias sobre genocidios o abusos. Es por eso que la gente no quiere saber del Tribunal Russell y ante esa disyuntiva, puede que los lectores sí sientan curiosidad por leer un cómic (Mac-Millan Kuthe, 2018: 756). Cortázar se adelanta a Maus y en su apuesta por el cómic es consciente de un potencial que atrae a muchos lectores.

El libro vivió una nueva versión publicada en 2002 con la edición española de Fantomas contra los vampiros multinacionales. Desde el mismo título, que suprime la coda "una utopía posible”, se advierten una serie de cambios que, como acertadamente señala Ana Merino, traicionan "la primera edición de Cortázar al no reproducir las viñetas originales del cómic [...] y poner en su lugar una serie de ilustraciones que tratan de parecer un cómic y que hacen que el texto pierda parte de su valor y contexto histórico creativo" (Merino, 2003: 67). Las ilustraciones y viñetas de Xavier

\footnotetext{
${ }^{13}$ Novela gráfica de Art Spiegelman publicada entre 1980 y 1991 que aborda la historia de un superviviente del Holocausto.
} 
Teixidó se alejan del arte de Víctor Cruz y a veces incurren, alejándose completamente del artefacto original publicado en 1975. El remedo compositivo funciona también como objeto híbrido pues fagocita elementos del cómic matricial, al que despoja de los elementos que presentaba la historieta mexicana. El procedimiento de la edición española resulta decepcionante y fallido, deturpando la orientación autoral de Cortázar, que concibe su texto con la incorporación al mismo de los pasajes de la historieta mexicana.

Sin justificar las convergencias que se pueden establecer entre el cómic y la literatura, Ana Merino alude al libro de Cortázar y reivindica del mismo, "los parámetros de diálogo que el cómic establece con la literatura, la realidad social, la imaginación popular, el trasfondo político e ideológico o el entorno estético de cada país como un rasgo más de su modernidad" (Merino, 2003: 26).

\section{La raíz hundida de todas las pesadillas: La raíz del ombú}

La Operación Cóndor y las dictaduras del Cono Sur impulsadas por la Inteligencia estadounidense funcionaron como espolón para disparar el compromiso de Cortázar como creador y como individuo. El empeño y los esfuerzos del escritor por intentar cambiar las cosas a partir de su arte, materializándose en un ejercicio de resistencia en la que Cortázar toma las armas letradas frente a la iniquidad y los crímenes:

Yo no podría escribir una novela ahora sí, mientras lo estoy haciendo, abro el periódico y me encuentro con lo que está sucediendo en Chile, en Uruguay o en Argentina; una injusticia ante la cual yo puedo tener una intervención de alguna eficacia, aunque sea una eficacia mínima, porque no me hago ilusiones respecto a los poderes de la literatura y la palabra. Pero ¿tú sabes lo que significa para mí el hecho de que, después de una ofensiva de telegramas, cartas, artículos, presiones sindicales, de todo, se consiga que sea puesto en libertad una persona que iba a ser ejecutada o que estaba siendo torturada? Esto justifica una vida. Si yo sigo, y seguiré, en este terreno es un poco por la recompensa de tipo humano. Porque, bueno, después puedo escribir un cuento sin sentirme tan desdichado, sin sentirme con tan mala conciencia (Montero, 1982: 12). 
Unos años después de Fantomas, el artista gráfico argentino Alberto Cedrón tantea la idea de una historieta con algunas implicaciones personales, contactando con Julio Cortázar, al que pide ayuda para dotar de sentido y orden narrativos a su propuesta. Cortázar se sumerge de nuevo en un material preexistente, pero con el que puede trabajar. De esta forma, el escritor argentino organiza en La raíz del ombú (1981) un relato coherente a partir del arte de Cedrón, la suma de sus talentos ofrece un relato de gran fuerza narrativa y gráfica.

Como todo acto de creación cortazariana, La raíz puede ser considerado un alegato, pues denuncia situaciones sufridas durante los regímenes dictatoriales y represivos de América Latina y se configura como una manifestación que alude directamente a la realidad del momento, marcada por la última dictadura argentina (1976-1983). Con esta historieta, el escritor pone de relieve su sensibilidad personal y adopta una posición en la que el intelectual actúa empleando los "nuevos medios de combate intelectual [...] la radio, la grabación de casetes o videos, la televisión, las fotonovelas, la música popular o las tiras cómicas" (Navarro, 2020: 157).

Al ser una propuesta de colaboración con Cedrón, ostenta una naturaleza más formal dentro de lo que se podría considerar como historieta tradicional. En el escaso medio centenar de páginas que integran la versión editada de 2004, la historieta se organiza a partir de distintas secuencias integrada exclusivamente por viñetas y recursos propios del cómic; no se intercalan separadamente fragmentos de prosa, insertos fotográficos, recortes, grabados o viñetas como ocurría en Fantomas ${ }^{14}$. La raíz dista mucho de ser una historieta convencional y presenta hibridaciones, puesto que está repleta de evocaciones oníricas como la imagen del del árbol del ombú ${ }^{15}$ junto con elementos narrativos que no siguen una estructura canónica y surgen del afán y de las búsquedas experimentales de Cortázar y de Cedrón. De esta manera, dentro de las unidades secuenciales de la historieta sí se advierte el uso de fotografías, collages u otras técnicas que demues-

14 "El hecho de que Cortázar insertase viñetas de cómic e ilustraciones en su narración confirmaba la importancia que este medio creativo de expresión ya había alcanzado en los 70" (Merino, 2003: 26).

${ }^{15}$ El ombú o bellasombra es un árbol autóctono del sur de Brasil, Paraguay, Uruguay y el Nordeste argentino, desde donde se ha expandido al resto del país, convirtiéndose en el árbol patrio de la Argentina. 
tran la tendencia del creador argentino a explorar el uso de la imagen, algo que a buen seguro no sedujo a muchos de los lectores del escritor y provoco discrepancias con la crítica (Navarro, 2020: 158).

El libreto de la historieta arranca de una idea de Cedrón, en la que Cortázar sitúa al personaje de Alberto, trasunto del artista, viviendo en una casa en medio del agro argentino. Un desconocido llega en un auto y decide ayudarle, desarrollando cierta confianza con él y relatándole la historia de su familia, remontándose a los tiempos en los que su abuelo, migrante italiano, llegó a la Argentina hasta el presente del relato, imbuido por el régimen de miedo y violencia impuesto por los hombres-larva. El racconto biográfico y familiar de Alberto termina trágicamente con su muerte, pues el desconocido es un terrorífico hombre-larva, ser mutante que encarna el mal y que será ajusticiado por los pescadores de la localidad cercana que, alertados por los disparos, encuentran al homicida y el cadáver de Alberto. La última página contiene un cartucho de texto como único elemento narrativo, mensaje de inquietante actualidad en el momento de la publicación y que se convierte en un llamado a todos para perseguir la verdad y luchar por ella:

El pescador tiene razón, así no se puede seguir.

¿Pero cómo hay que seguir?

Esta historia continua más allá del papel. Esta historia no es más que un pedacito de historia argentina. El resto está en manos de todo el pueblo. (Cortázar y Cedrón, 2004: 53).

El acabado clásico de las viñetas de Víctor Cruz en Fantomas otorgaba un equilibrio formal al relato cortazariano. En cambio, La raíz presenta una visualización recargada del desasosiego, siendo este permanente a lo largo de una serie de imágenes desbordantes en las que Cedrón aplica un estilo en el que mezcla distintas técnicas pictóricas con recortes de fotografías antiguas, aplicando desde collages a acuarelas o dibujos a carboncillo. Los rasgos surrealistas de la historieta pueden estar vinculados a distintos artistas del underground norteamericano, aunque quizá la referencia que mejor se aprecia en La raíz es la cercanía con las propuestas plásticas de 
Terry Gilliam, cineasta y artista heterodoxo integrante del grupo cómico británico Monty Python. El aparato gráfico de Cedrón en la historieta comparte con Gilliam una común irreverencia y una tendencia por la disolución de formatos y géneros. Cedrón aplica técnicas disruptivas que rechazan los esquemas más canónicos de las representaciones figurativas y se caracteriza por su naturaleza testimonial, yuxtaponiendo la experiencia autobiográfica con el sentir colectivo, empleando una paleta de colores fríos, impregnándose los recuerdos "con un colorido que se desvanece tras irrumpir los hombres-larva. Este acontecimiento marca el regreso a la monocromía, que se incrementa al acercarse el desenlace de la historia, con el asesinato de Alberto" (Navarro, 2020: 158).

Como señala José Enrique Navarro, la aparición de La raíz de ombú se publica en una tirada escasa de ejemplares en Caracas. La empresa editora es Cadafe, el ente público venezolano de energía eléctrica. La publicación en Venezuela se produjo por cuestiones políticas y ante la imposibilidad de editarse en Argentina en un turbulento y aciago recorrido (Navarro, 2020: 159) hasta que, en 2004, la historieta vive una nueva edición en Buenos Aires. El libro, veintitrés años después, es publicado en edición rústica con mejor acabado y reproducción que esa primera edición de la historieta.

La raíz podría ser calificada de historieta distópica pero la opresiva realidad resultaba aún más desoladora que el relato de Cedrón y Cortázar, estimulando reflexiones recurrentes en las narraciones cortazarianas, como muy bien se advierte en el extracto de una entrevista en francés que se puede encontrar en el documental Cortázar (1994) del director Tristán Bauer. El escritor detalla y expone cómo tras caer el sol, paseando por Buenos Aires o París de noche, "en ese estado deambulatorio en el que dejamos de pertenecer al mundo ordinario" y en el suspenso nocturno, es donde se produce el fluir de sus relatos, porque como ocurre en La Raíz, la noche hace que la narración engulla al lector en el misterio para darnos instantes que no sólo rompen con lo ordinario, pues suscitan una gran perturbación. Así, se generan espacios en los que encontrar la verdad o bien, acercarse a la misma, suele ser el objetivo que persigue la obra cortazariana y de esta forma de iluminación en que las sombras del horror encarnadas por esa metáfora tangible y alucinada que encarnan los hombres-larva. La pesadilla no es imaginada porque las atrocidades ejecutadas por la dictadura no lo son. En esa sociedad controlada por la máquina bélica, el miedo fundado 
sirve para estar alerta frente a las maquinaciones de los hombres-larva, que aniquilan toda disidencia o forma de libertad hasta el recuerdo es subversivo. Por eso, aunque La raíz se exprese desde parámetros fantásticos, resulta un contexto muy verosímil.

En el proceso de muchas de sus creaciones, Cortázar lo relaciona con una imagen capital de los imaginarios surrealistas y enumera a las constelaciones de frases y emociones que no pueden expresarse con palabras. Lo cifra en un lugar del Pont Neuf y esa evocación mistérica de los lienzos de Paul Delvaux, la inminencia de algo que se va a manifestar y que se sitúa fuera de las categorías lógicas y de los acontecimientos ordinarios, las coordenadas también de las producciones cortazarianas que cabalgan en una suma de fantasías y realidades pedestres (Bauer, 1994, 50:33-54:50). Una percepción de lo fantástico que se retrotrae a los cuentos de Bestiario (1951), una noción que Cortázar considera que es muy personal pues entendía las situaciones fantásticas en la literatura o en la vida con normalidad, peripecias que entrecruzaban en paralelo a la propia existencia y a la creación artística del escritor argentino (Soler-Serrano, 1977b, 45:1048:30).

Del mismo modo y retomando la idea de lo distópico, comparando las temáticas de La raíz y de El Eternauta (1957-1959) de Francisco Solano y Oesterheld, se sugiere que el asesinato del personaje de Alberto se relaciona con la eliminación sistemática del otro, alegoría de "la desaparición masiva, aunque no siempre cruenta, representa el rasgo temático que une las obras y las relaciona con el evento apocalíptico, caracterizado justamente por la catástrofe colectiva" (Magnani, 2013: 389). La obra de Solano y Oesterheld ha vivido diversas reapropiaciones políticas (Magnani, 2013: 393), en contraste, difícilmente los cómics de Cortázar, Fantomas y sobre todo La raíz podrían ser "víctimas" de una reapropiación política, siendo marginales a la popularidad de las historietas de Oesterheld. Hay otro motivo que diluye la posibilidad de una apropiación ideológica de las historietas cortazarianas, algo fundamentado en que sus propuestas estéticas y narrativas cuentan con protagonistas de difícil mitificación, como el enmascarado Fantomas, que no es un héroe al uso o Alberto, mártir que encarna lo colectivo, lejos de las virtudes que pudiera encarnar el Juan Salvo de $E l$ Eternauta. 


\section{Discusión y conclusión}

Al pensar en ambas propuestas, Fantomas y La raíz, las dos historietas ofrecen un espacio para pensar en la dimensión creativa de Cortázar. Los dos libros se cuestionan la violencia como medio para imponer voluntades, desde la posición adoptada por los Estados Unidos apoyando y reforzando las distintas dictaduras que se suceden en América Latina en la segunda mitad del siglo XX y las prácticas de estos regímenes políticos de aplicarse con saña ante cualquier disidencia. En las historietas del escritor argentino se da voz a aquellas reivindicaciones silenciadas sobre los abusos y tropelías cometidos en la región. Por eso sus narraciones figurativas no son fruto del azar. Junto con el concurso del material previo de Martré y Cruz, sumado al aparato gráfico dispuesto por Alberto Cedrón, Cortázar elabora dos relatos críticos que sirven para denunciar las violaciones de los Derechos Humanos y las explotaciones sufridas en América Latina, consideraciones extensivas a las prácticas neocoloniales que se producen en todo el mundo.

Del mismo modo que la literatura cortazariana puede distinguirse en matices de musicalidad y ritmo, lo es también que el escritor demuestra un enorme caudal de recursos al afrontar la escritura secuencial. Por eso, es demasiado reductivo, cuando no gratuito, afirmar que la obra de Cortázar es profundamente visual, porque lo es de la misma manera que sus propuestas narrativas presentan un aparato visual notable, pero también es deudora de esa cadencia improvisatoria del jazz o a veces de la turbulencia dancística y arrebatadora del tango. Las características descritas se relacionan con lo que el propio escritor describió como "la bancarrota de los géneros”, una percepción que le llevó a no desdeñar ninguna forma narrativa.

Escapando a la rigidez de ciertas jerarquías, con estas historietas la producción cortazariana alcanzó instancias que iban más allá, fortaleciendo las ideas y los planteamientos desplegados en su obra. Atendiendo a la diversidad estética y narrativa de Cortázar, sus creaciones siguen conformando "una enciclopedia de la modernidad [...] empalada en eso que hoy llamamos postmodernidad" (Alazraki, 1989: 3). El compromiso en un escenario hostil permite que a la preocupación de Cortázar por la forma se le añada un alto sentido cívico y político característico en su obra y es por 
eso que, en América Latina, el escritor argentino encarna a un "gran renovador de lenguajes, de formas y de ópticas literarias, [...] constituye un raro caso del escritor en que el alto humanismo de su obra lo obliga a recorrer los fastos de la historia y a confrontarse con su tiempo" (Alazraki, 1989: 4).

La fuerza de los cómics en los que participó Cortázar compone un turbador recorrido por imágenes de una potencia visual que confluyen con la capacidad de la prosa cortazariana por proyectar una visualización tan lúcida como sugestiva, tan lacerante y luminosa que cubre desde el sentir individual a las aspiraciones colectivas más loables, caracterizada por "esa ética, no de preceptos ni de moralidades sino de conciencia política hacia Latinoamérica” (Alazraki, 1989: 18).

Cortázar instalado en la urgencia del presente ofreció ejemplos notables de esa aspiración por narrar lo que ocurría: una realidad de abusos y crímenes que se perpetúa sin que se erradiquen definitivamente las acciones y decisiones políticas más infames, pues contumazmente la historia tiene el vicio de replicar afrentas y agravios. La vigencia de ese pensador comprometido que fue el escritor nacido en Bruselas se fundamenta en su alta conciencia política, alejada del proselitismo doctrinario, y en sus creaciones, de las que emanan un hondo sentido y espíritu críticos. Denuncias y reflexiones irónicas que se alejan del dogmatismo y que denotan su responsabilidad intelectual en obras como Fantomas. Al reconocer la ausencia del humor y la capacidad en el ámbito cultural y creativo de lo hispanoamericano frente al distanciamiento cómico de los anglosajones, Cortázar razonaba que, desde su compromiso creativo, su intención era activar el humor al describir o introducir las situaciones más trágicas, en un proceso de distanciamiento del espanto (Soler-Serrano, 1977a, 15:3516:51). Un flujo de humor curativo y terapéutico que, sin embargo, apenas se intuye en la sátira distanciada de la dictadura expresada que es La raíz del ombú. El escritor asume los resortes del medio narrativo y se propone avanzar en el mismo, componiendo en sus aportaciones historietísticas una serie de escenarios del universo ficcional cortazariano, tan proclive a proyectar relatos subyugantes, a veces tortuosos, pero jamás indiferentes. En las narraciones gráficas de Cortázar se apela a la culminación última de esas escasas experiencias catárticas que, al mismo tiempo reveladoras y liberatorias para el lector, son expresiones que se deben atesorar siempre. 


\section{Referencias}

Alazraki, Jaime. (1989). "Imaginación e historia en Julio Cortázar”. En Neumeister, Sebastián (coord.). Actas del IX Congreso de la Asociación Internacional de Hispanistas, 1986 (pp. 3-20). Berlín: Vervuert.

Altarriba, Antonio. (2011). "Introducción sobre el origen, evolución, límites y otros debates teóricos en torno a la historieta”. Arbor. Revista de Ciencia, Pensamiento y Cultura, n. Extra-2, 9-14. DOI: https://doi. org/10.3989/arbor.2011.2extran2111 Consultado el 24 de octubre de 2020.

Artiaga, Loïc. (2013). "Le Bleu et le noir. Fantômas, le temps des guerres chromatiques (1962-1969)”. Belphégor [En línea], vol. 11, n. 1. DOI: https://doi.org/10.400o/belphegor.79 Consultado el 11 de octubre de 2020.

Bauer, Tristán. (director). (1994). Cortázar. Argentina: La Zona.

Cortázar, Julio. (1975). Fantomas contra los vampiros multinacionales: una utopía realizable. México: Excélsior.

Cortázar, Julio y Breccia, Enrique. (2007). Reunión. Barcelona: Editorial Libros del Zorro Rojo.

(2002). Fantomas contra los vampiros multinacionales. Barcelona: Destino.

Cortázar, Julio y Cedrón, Alberto. (1981). La raíz del ombú. Caracas: Cadafe.

. (2004). La raíz del ombú. Buenos Aires: Fundación Internacional.

Cortázar, Julio y Muñoz, José. (2009). El perseguidor. Barcelona: Editorial Libros del Zorro Rojo.

García-Reyes, David. (2020). "Reescrituras en Soldados de Salamina o las sendas de la memoria: Desplazamientos de la literatura en el cine y en la narración figurativa”. Trasvases entre la literatura y el cine, vol. 2, 271-291, 2020. ISSN 2695-639X. DOI: https://doi.org/10.24310/Trasvasestlc.vi2.9191 Consultado el 9 de julio de 2020.

González Bermejo, Ernesto. (1978). Conversaciones con Cortázar. Barcelona: Edhasa. 
López Petzoldt, Bruno. (2014). Los relatos de Julio Cortázar en el cine de ficción (1962-2009). Madrid/Frankfurt Am Main: Iberoamericana/ Vervuert.

Mac-Millan Kuthe, Mary Fleur. (2017). "Ética/estética en Fantomas contra los vampiros multinacionales de Julio Cortázar: una relación suplementaria”. ALPHA: Revista de Artes, Letras y Filosofía, n. 45, 171-184. . (2018). "La función del cómic en Fantomas contra los Vampiros Multinacionales de Julio Cortázar (1975): del fetiche al duelo”. Revista Iberoamericana, n. 264, 747-758.

Magnani, Ilaria. (2013). "Versatilidad política del paradigma apocalíptico: tres variantes contemporáneas”. Altre Modernità: Rivista di studi letterari e culturali, n. Extra-1, 385-395.

Marchamalo, Jesús (2011). Cortázar y los libros. Madrid: Fórcola Ediciones.

Marchamalo, Jesús y Torices, Marc (2017). Cortázar. Madrid: Nórdica Libros.

Martré, Gonzalo. (2014). "La verdadera historia de Cortázar y Fantomas", Milenio, 28 de septiembre. Recuperado de https://www.milenio.com/ blogs/qrr/la-verdadera-historia-de-cortazar-y-fantomas Consultado el 15 de agosto de 2020.

Martré, Gonzalo y Cruz, Víctor. (1975). "La inteligencia en llamas”. Fantomas: la amenaza elegante, n. 201. México: Editorial Novaro.

Merino, Ana. (2003). El cómic hispánico. Madrid: Cátedra.

(2011). "Entre el margen y el canon: pensamientos discursivos alrededor del cómic latinoamericano”. Revista Iberoamericana, n. 234, 13-18.

Montero, Rosa. (1982). "El camino de Damasco de Julio Cortázar”. El País Semanal, 14 de marzo, pp. 12-14.

Navarro, José Enrique. (2020). "Política, estética y fantasía en La raíz del ombú, de Julio Cortázar y Alberto Cedrón”. Symposium: A Quarterly Journal in Modern Literatures, n. 74, 3, 155-167. Recuperado de https://doi.org/10.1080/o0397709.2020.1777734 Consultado el 14 de septiembre de 2020. 
Soler-Serrano, Joaquín (director y presentador). (1977a). Julio Cortázar en A fondo II. España: RTVE. Recuperado de https://www.rtve.es/ alacarta/videos/a-fondo/entrevista-julio-cortazar-programa-fondoii/1051555/ Consultado el 14 de septiembre de 2020.

. (1977b). Julio Cortázar en A fondo I. España: RTVE. Recuperado de https://www.rtve.es/alacarta/videos/a-fondo/entrevista-julio-cortazar-programa-fondo/1051583/ Consultado el 14 de septiembre de 2020. 